\title{
Some Effects of Postnatal Zinc Deficiency on Developing Rat Brain
}

\author{
G. J. FOSMIRE, Y. Y. AL-UBAIDI, AND H. H. $\operatorname{SANDSTEAD}^{(35)}$ \\ United States Department of Agriculture, Agricultural Research Service, Human Nutrition Laboratory, \\ Grand Forks, North Dakota, USA
}

\section{Extract}

A deficiency of dietary zinc during the suckling period of the rat results in a depression in normal growth, which is, in part, due to the inanition experienced by the dam. The pups from such zinc-deficient dams have smaller forebrains at all of the time intervals investigated in comparison with pups from both zinc-adequate controls. The cell number of the forebrain of the zinc-deficient pup was also reduced in comparison with the zinc-adequate pups. RNA concentration did not appear to be affected, although the total RNA content was reduced because of the smaller brain size. The amount of protein per cell was reduced at 6 and 15 days in the zinc-deficient forebrain and polysomal profiles displayed abnormal distribution of material between monosomes and polysomes in the zinc-deficient brain. Zinc deficiency during the suckling period thus appears to disadvantage the animal in terms of body, brain growth, accretion of cells into the forebrain, and normal protein metabolism.

\section{Speculation}

Zinc is essential for development of the brain. Infants who experience zinc deficiency during the critical period for brain growth will suffer brain damage which may be poorly reversible.

Zinc has been known to be an essential trace element for more than a century (17), although its essentiality for a mammalian species was not established until 1934 (28), when the deficiency syndrome was produced in rats. The manifestations of zinc deficiency have been reviewed by Underwood (29); they include growth retardation, anorexia, parakeratosis of the skin and esophagus, abnormal bone maturation, unsteady gait, and impaired reproductive performance. If the deficiency is induced soon after conception, there is an increased incidence of abortion, teratology, and growth failure in the young $(10,26)$.

Zinc deficiency has its most profound effects on growing or rapidly proliferating tissues. In an altricial animal, such as the rat, the brain is not well developed at birth and thus there is considerable growth and maturation of the brain in the neonate. The occurrence of zinc deficiency during the early life of the rat might be expected to seriously impair normal growth and development of the brain. Hurley and Shrader (9) have shown that inadequate levels of zinc during prenatal development can lead to serious teratology with gross malformations of the brain in $47 \%$ of the fetuses. Depriving the suckling pup of adequate zinc by feeding the nursing dam a deficient diet will cause severe growth retardation by the ninth day. Brains from such 12-day-old zinc-deficient pups show decreased amounts of cerebellar lipids compared with pups suckled by zinc-adequate, pair-fed, or ad libitum-fed dams. The 12-day-old zinc-deficient pups also displayed a decreased incorporation of thymidine into DNA and of inorganic sulfate into the acid-insoluble fraction of brain (19). The studies reported in this paper are an extension of the above studies on effects of a deficiency of dietary zinc on brain composition and development during the suckling period.

\section{METHODS}

Pregnant Sprague-Dawley rats were fed an adequate ration ad libitum until delivery. As soon as possible after parturition, the dams were moved to clean Plexiglas cages. The number of pups in each litter was made equivalent at 8 and only litters that were maintained at 7 or 8 pups during the test period were used for analysis. All animals were then fed a biotin-enriched, $20 \%$ sprayed egg white diet (13) which was modified to incorporate inositol at $1 \mathrm{~g} / \mathrm{kg}$ and to omit the antibiotic. The zinc content was less than $1 \mathrm{mg} / \mathrm{kg}$ by analysis. One group of dams was given the diet ad libitum and distilled, deionized water to drink. Two zinc-adequate controls were utilized. The first was pair-fed on an individual basis with the dams in the zinc-deficient group. The second control was fed the diet ad libitum. Both zinc-adequate controls received zinc at $100 \mathrm{mg} /$ liter in their drinking water.

At intervals, the entire litter of a dam was killed by decapitation. The brains were rapidly removed, separated by blunt dissection into cerebellum and forebrain (the brain anterior to the cerebellum excluding the brain stem and olfactory bulbs), and placed in ice-cold, buffered sucrose. After weighing, the tissues were homogenized in $0.25 \mathrm{M}$ sucrose containing $25 \mathrm{mM} \mathrm{KCl}, 5 \mathrm{mM} \mathrm{MgCl}_{2}$, and $50 \mathrm{mM}$ Tris- $\mathrm{HCl}, \mathrm{pH} 7.5$, by using glass homogenizers with Teflon pestles.

Aliquots of the homogenate were analyzed in triplicate for DNA by using Burton's modification of the diphenylamine procedure (1). Separate aliquots were analyzed in triplicate for RNA by ultraviolet absorption after hydrolysis in $0.3 \mathrm{~N} \mathrm{KOH}$ as described by Fleck and Munro (3) and for protein by using Hartree's modification (8) of the Lowry procedure (12). Numbers of determinations performed are given in the tables and legends to the figures.

The postmitochondrial supernatant was treated with deoxycholate $(0.5 \%$ final concentration $)$, recentrifuged at $4000 \mathrm{rpm}$, $4^{\circ}$, and the resultant supernatant solution layered over a $15.5-35.5 \%(\mathrm{w} / \mathrm{v})$ linear sucrose gradient containing $5 \mathrm{mM}$ Tris, $25 \mathrm{mM} \mathrm{KCl}$, and $5 \mathrm{mM} \mathrm{MgCl}_{2}, \mathrm{pH}$ 7.5. After centrifugation for $160 \mathrm{~min}, 284,000 \times g_{\max }, 4^{\circ}$, the gradients were displaced from the bottom and the absorbance at $260 \mathrm{~nm}$ monitored with a spectrophotometer by using a 2-mm light path flow-through cell. 


\section{RESULTS}

One of the manifestations of zinc deficiency in the young animal is depression of normal growth. Figure 1 shows a typical growth pattern, this being for an experimental group terminated at 16 days. Growth proceeded more slowly in the litters nursed by zinc-deficient or pair-fed dams than in those nursed by zinc-adequate, ad libitum-fed dams. Growth of the zinc-deficient pups and pups from the pair-fed dam was similar, however.

The brain weights also were affected by zinc deficiency or undernutrition. This is represented in Figure 2. By 6 days, the forebrains of the zinc-deficient pups were significantly smaller than those from the pair-fed dams $(P<0.01)$ or the ad libitum-fed controls $(P<0.01)$. At subsequent ages (i.e., 11, 15 , and 21 days), the brains remained significantly different in weight ( $P<0.01$ for all comparisons).

Analysis of the brains for DNA content at several periods showed an analogous pattern to brain weight. The pattern of DNA accretion is shown in Figure 3. The differences between the three test groups do not appear as grêat as the differences between the brain weights, but at all ages, the zinc-deficient pups had less total DNA in their forebrain, the pups from the pair-fed dams had an intermediate amount, and the pups from the zinc-adequate, ad libitum-fed control had the most.

Analysis at several intervals during the 21-day, suckling period for RNA content were performed. When the data were calculated in terms of the amount of RNA per milligram wet weight of tissue, the effects of zinc deficiency or undernutrition were not very great (Tables 1 and 2). For all three test

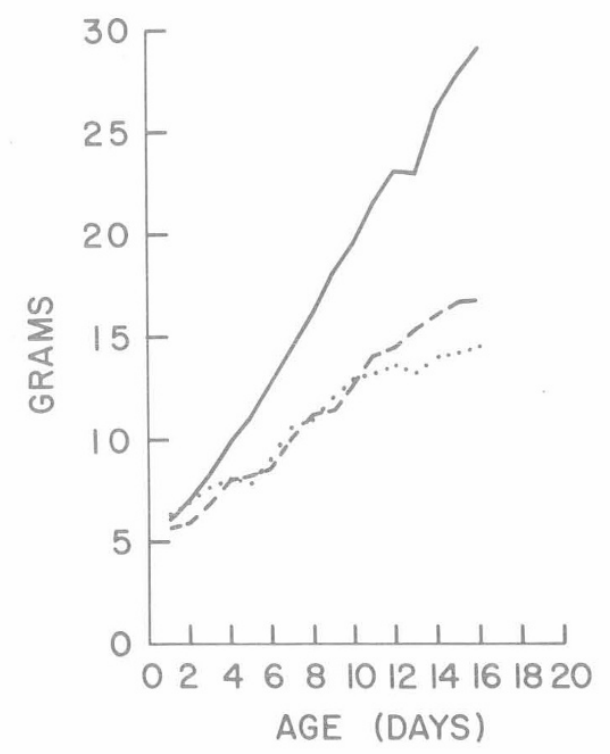

Fig. 1. Growth of body weight of rat pups suckled by dams fed a zinc-deficient diet (...), pair-fed, given adequate zinc (--) or fed ad libitum, given adequate zinc (-). These are average weights of eight pups in each litter. groups, the RNA concentration declined with increasing age. The total RNA was consistently less in the forebrain from the zinc-deficient pup and intermediate in the pup from the pair-fed dam. Significant differences in total RNA were found between the zinc-deficient and pair-fed pups compared with the ad libitum pups. Differences between the zinc-deficient and pair-fed pups were significant only on the 11 th day.

Protein composition of the forebrain (Tables 3 and 4)

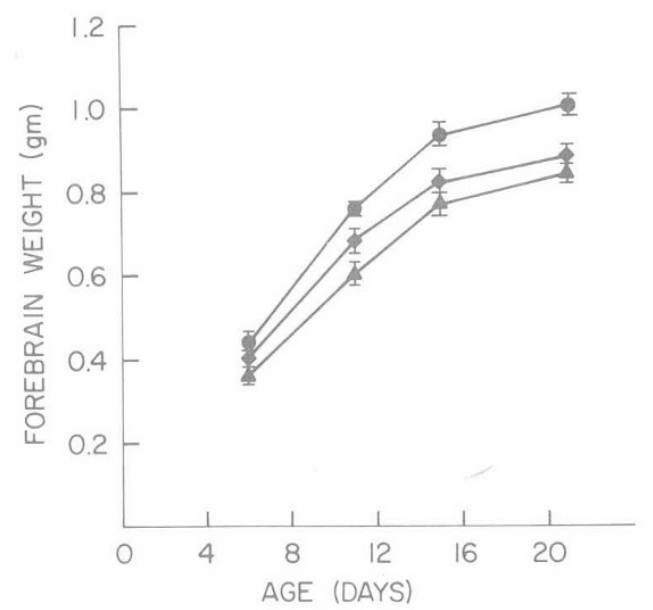

Fig. 2. Weights were derived from 12 brains in each group at 6 days, 8 in each group at 11 and 16 days, and 14 in each group at 21 days and represent pups drawn from at least two litters for each test group at

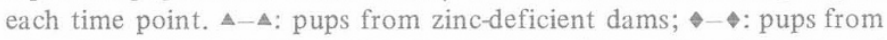
zinc-adequate, pair-fed dams; $\bullet \bullet$ : pups from zinc-adequate, ad libitum-fed dams.

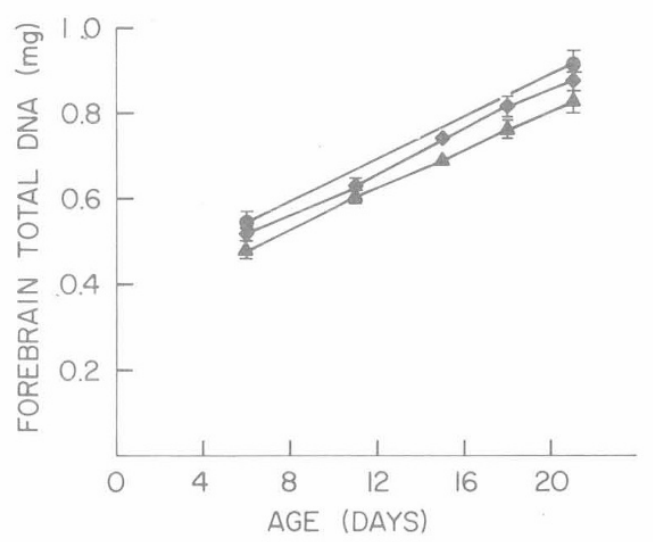

Fig. 3. Total DNA content in the forebrain of zinc-deficient pups $(\mathbf{\Delta}-\mathbf{\Delta})$, pups from zinc-adequate, pair-fed dams $(\bullet-\downarrow)$, and zinc-adequate, ad libitum-fed dams $(\bullet-\bullet)$. Values are means with brackets to indicate the $\mathrm{SE}$ of the means and represent eight individual determinations for each group at 6 days and four individual determinations at the subsequent ages.

Table 1. RNA content of forebrain of rat pups from zinc-deficient, pair-fed, or ad libitum-fed dams

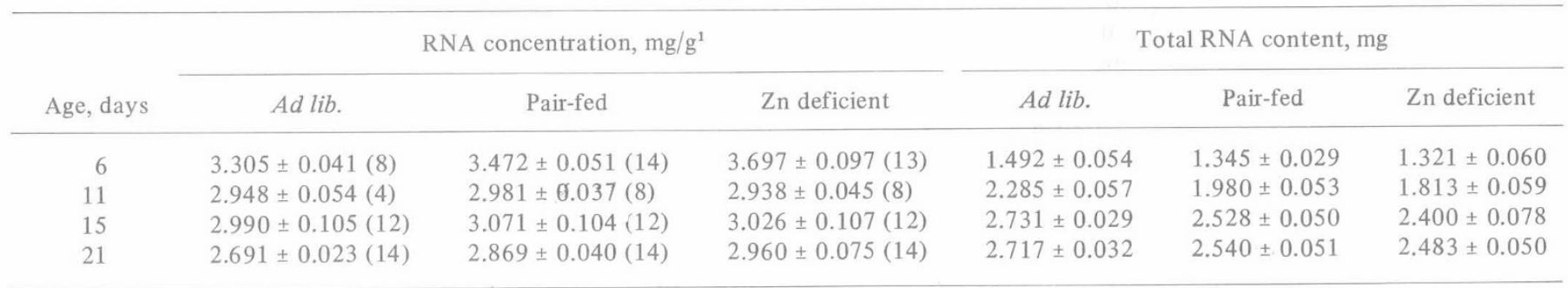

${ }^{1}$ Values are expressed as means $\pm \mathrm{SE}$ and the number of determinations are indicated in parentheses. 
revealed no significant differences in the concentration of protein between the zinc-deficient pups and pups from the pair-fed dams. The total amount of brain protein which is consistent with brain size was less in the zinc-deficient pups compared with pair-fed pups at each interval, whereas the protein per cell (i.e., per amount of DNA) was reduced at both 6 and 15 days in the zinc-deficient group compared with the pair-fed controls. This reduction of protein per cell may indicate either impaired synthesis or increased degradation of protein. The possibility that protein synthesis was impaired prompted the measurement of the polysomal profile at several ages. Representative traces are presented in Figure 4 for profiles obtained using homogenates of whole brain at 5 days of age. The profile of the zinc-deficient pup is seen to have an altered distribution of material between the monosomes and polysomes. An increase in monosomes is apparent, whereas polysomes appear to be decreased. The polysome profile of the brain of the pups nursed by the pair-fed dam was also abnormal in comparison with the pup nursed by the ad libitum dam. Thus it appears that undernutrition had an adverse effect on the profile which was less severe than that caused by zinc deficiency. Similar observations were obtained at other times during the first 13 days postnatally (Table 5).

\section{DISCUSSION}

A lack of adequate zinc can have very severe consequences for the growing animal (29). Growth is depressed and the animal displays a variety of defects in its normal metabolism. Hurley and Shrader (9) have observed some of the histologic manifestations of a severe zinc deficiency on the prenatal development of the brain. The response of the postnatal brain to a lack of this essential trace element has not been completely documented to date. Previous reports $(5,19)$ have discussed some of the biochemical abnormalities observed during the maturation of the neonatal brain not supplied with adequate zinc.

The growth depression commonly observed in zinc deficiency has been confirmed in the experimental situation reported here. Inanition must play a predominant role in the growth depression initially since the zinc-deficient pups and the zinc-adequate, but undernourished pups, i.e., from pair-fed dams, displayed very similar growth patterns. During the latter portion of the suckling period, the zinc-deficient pups grew at a slower rate than did pups from the pair-fed dams. Thus there

Table 2. Significance of differences in total RNA of forebrain ${ }^{1}$

\begin{tabular}{cccc}
\hline Age, days & $\begin{array}{c}\text { Ad lib. vs. } \\
\text { Pair-fed }\end{array}$ & $\begin{array}{c}\text { Ad lib. vs. } \\
\text { Zn deficient }\end{array}$ & $\begin{array}{c}\text { Pair-fed } v s . \\
\text { Zn deficient }\end{array}$ \\
\hline 6 & $P<0.01$ & $P<0.05$ & NS \\
11 & $P<0.01$ & $P<0.01$ & $P<0.05$ \\
15 & $P<0.01$ & $P<0.01$ & NS \\
21 & $P<0.01$ & $P<0.01$ & NS \\
\hline
\end{tabular}

${ }^{1}$ NS: not significant. is an apparent additive insult in that the deficiency and the undernutrition combine to slow growth further. The lag in growth of the zinc-deficient pups compared with the pair-fed pups may be a reflection of impaired food utilization in zinc deficiency as has been described by Somers and Underwood $(24,25)$.

The brain of the adult animal appears to be very resistant to alterations in its nutrition (2). The brain of the young animal, however, is quite susceptible to a number of nutritional deprivations or excesses. Depriving the suckling pup of adequate nutriture by placing large litters (16-18 animals) on the dams resulted in reduced brain weights $(7,30)$. The growth of the neonatal brain appears to be more affected by zinc deprivation than is reflected in a response in body weight. Thus at 6 days of age, the zinc-deficient animals displayed significantly reduced brain weights when compared with pups from pair-fed $(P<0.01)$ or ad libitum-fed $(P<0.01)$ control dams although the body weights were not significantly different. Apparently the lack of adequate zinc had a profound effect on brain growth that was in addition to the effect of the associated inanition which occurs in zinc deficiency as a consequence of anorexia.

Previous work has shown that undernutrition during the suckling period reduced the level of DNA in the brain and that this reduction was not corrected by rehabilitative feeding for several weeks after weaning $(7,15,30)$. Similar reductions in the DNA content with undernutrition were observed when undernourished, i.e., pups from the pair-fed controls, were compared with the pups from the zinc-adequate, ad libitumfed dams. The zinc-deficient pups were more severely affected than the undernourished pups; total DNA levels were lower at all ages investigated. Previous work demonstrated reduced

Table 4. Significance of protein content of postnatal rat forebrain ${ }^{1}$

\begin{tabular}{|c|c|c|c|}
\hline Age & $\mathrm{mg} / \mathrm{g}$ & Total protein & DNA, $\mathrm{mg} / \mathrm{mg}$ \\
\hline \multicolumn{4}{|l|}{6 days } \\
\hline $\mathrm{A} v s . \mathrm{P}$ & $<0.01$ & NS & $<0.01$ \\
\hline A vs. D & $<0.01$ & $<0.01$ & NS \\
\hline Pvs. D & NS & $<0.010$ & $<0.01$ \\
\hline \multicolumn{4}{|l|}{11 days } \\
\hline A vs. P & $<0.01$ & $<0.01$ & \\
\hline A vs. D & $<0.01$ & $<0.01$ & \\
\hline P vs. D & NS & $<0.01$ & \\
\hline \multicolumn{4}{|l|}{15 days } \\
\hline A vs. P & NS & $<0.05$ & NS \\
\hline A vs. D & NS & $<0.01$ & $<0.05$ \\
\hline $\mathrm{P} v s . \mathrm{D}$ & NS & $<0.01$ & $<0.01$ \\
\hline \multicolumn{4}{|l|}{21 days } \\
\hline $\mathrm{A} v s . \mathrm{P}$ & NS & $<0.01$ & \\
\hline A vs. D & NS & $<0.01$ & \\
\hline P vs. D & NS & $<0.01$ & \\
\hline
\end{tabular}

${ }^{1}$ NS: not significant; A: ad libitum-fed dams; P: pair-fed dams; D: Zn-deficient dams.

Table 3. Protein content of postnatal rat forebrain ${ }^{1}$

\begin{tabular}{|c|c|c|c|c|c|c|c|c|c|}
\hline \multirow[b]{2}{*}{$\begin{array}{l}\text { Age, } \\
\text { days }\end{array}$} & \multicolumn{3}{|c|}{ Ad libitum } & \multicolumn{3}{|c|}{ Pair-fed } & \multicolumn{3}{|c|}{$\mathrm{Zn}$ deficient } \\
\hline & $\begin{array}{l}\text { Conc, } \\
\mathrm{mg} / \mathrm{g}\end{array}$ & $\begin{array}{c}\text { Total, } \\
\text { mg }\end{array}$ & $\begin{array}{l}\text { Protein/ } \\
\text { DNA, } \\
\text { mg/mg }\end{array}$ & $\begin{array}{l}\text { Conc, } \\
\mathrm{mg} / \mathrm{g}\end{array}$ & $\begin{array}{c}\text { Total, } \\
\text { mg }\end{array}$ & $\begin{array}{l}\text { Protein/ } \\
\text { DNA, } \\
\mathrm{mg} / \mathrm{mg}\end{array}$ & $\begin{array}{c}\text { Conc, } \\
\mathrm{mg} / \mathrm{g}\end{array}$ & $\begin{array}{c}\text { Total, } \\
\text { mg }\end{array}$ & $\begin{array}{l}\text { Protein/ } \\
\text { DNA, } \\
\text { mg/mg }\end{array}$ \\
\hline 6 & $56.5 \pm 1.7$ & (8) $25.3 \pm 0.3$ & $46.4 \pm 0.5$ & $65.6 \pm 0.6$ & (14) $25.0 \pm 0.4$ & $51.3 \pm 0.8$ & $65.0 \pm 0.8$ & (13) $22.1 \pm 0.4$ & $46.8 \pm 1.3$ \\
\hline 11 & $81.1 \pm 2.3$ & (8) $61.3 \pm 1.5$ & & $71.2 \pm 1.4$ & (11) $49.1 \pm 1.1$ & & $71.7 \pm 1.4$ & (12) $44.8 \pm 0.9$ & \\
\hline 15 & $87.1 \pm 1.8$ & (12) $82.5 \pm 1.5$ & $72.5 \pm 4.6$ & $87.7 \pm 1.4$ & (12) $76.5 \pm 2.5$ & $74.9 \pm 2.1$ & $86.2 \pm 1.6$ & (12) $61.9 \pm 1.4$ & $62.0 \pm 1.9$ \\
\hline 21 & $81.5 \pm 1.2$ & (10) $85.6 \pm 1.6$ & & $85.8 \pm 2.8$ & (10) $77.4 \pm 2.5$ & & $79.4 \pm 1.6$ & (10) $68.2 \pm 1.8$ & \\
\hline
\end{tabular}

${ }^{1}$ Values are means \pm SE. Numbers of determinations is shown in parentheses. 


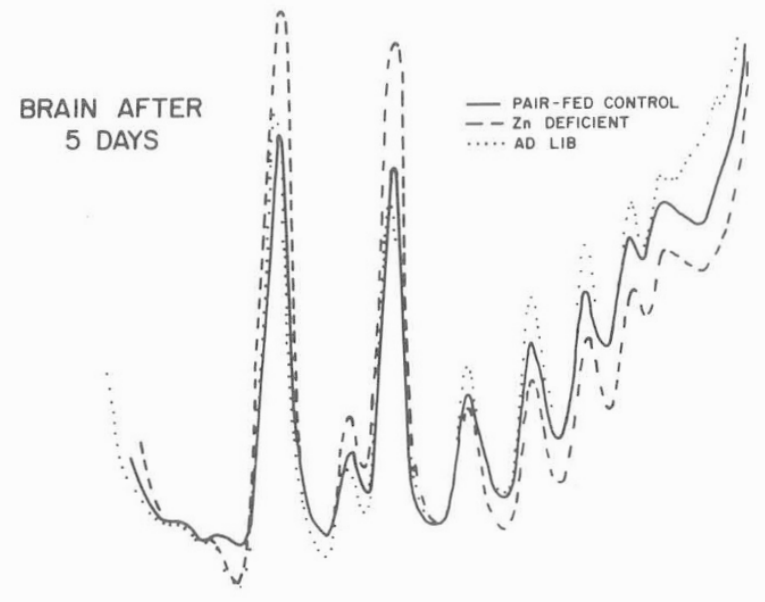

Fig. 4. Sedimentation profiles of rat brain polysomes in continuous sucrose gradient $(15.5-35.5 \% \mathrm{w} / \mathrm{v})$. Each profile was isolated from the deoxycholate-treated $(0.5 \%$ final concentration $)$ postmitochondrial supernatant derived from the whole brain of four pups. The absorbance at $260 \mathrm{~nm}$ was monitored automatically in a Gilford model 2400 spectrophotometer (31) (top of the gradient is to the left of the figure).

Table 5.Distribution of material between polysomes and monosomes as observed by centrifugation on a linear sucrose gradient

\begin{tabular}{ccc}
\hline $\begin{array}{c}\text { Age and } \\
\text { treatment }\end{array}$ & Monosome, $\%$ & Polysome, $\%$ \\
\hline 3 days & & \\
D & 25.9 & 74.1 \\
P & 25.4 & 74.5 \\
5 days & & \\
D & 39.4 & 60.9 \\
P & 27.2 & 72.7 \\
A & 26.1 & 73.8 \\
5 days & & \\
D & 42.7 & 57.3 \\
P & 24.9 & 75.1 \\
7 days & 46.3 & 53.7 \\
D & 31.8 & 68.2 \\
P & 17.9 & 82.1 \\
A & 44.6 & 55.4 \\
13 days & 29.8 & 70.2 \\
D & & \\
P & & \\
\hline
\end{tabular}

${ }^{1}$ D: Zn-deficient dams; P: pair-fed dams; A: ad libitum-fed dams.

incorporation of thymidine into DNA in liver parenchymal cells from zinc-deficient rats (20) and reduced synthesis of DNA in the liver of zinc-deficient rats after partial hepatectomy (6). The observations that DNA synthesis in animal cells requires zinc (18) and that Escherichia coli and sea urchin DNA polymerases are zinc metalloenzymes (23) would seem to implicate zinc as having a fundamental role in DNA synthesis.

The concentration of RNA in the forebrain does not appear to be substantially altered by either undernutrition or zinc deficiency (Tables 1 and 2). The total amount of RNA was reduced in the zinc-deficient and undernourished forebrain; the reductions occurred in response to brain size. A normal developmental pattern of RNA concentration (milligrams per gram wet weight) was maintained in all three test groups. This is of interest since RNA polymerase is reduced with zinc deficiency in neonatal rat liver (27) and the RNA polymerase catalyzing the synthesis of ribosomal RNA in forebrain and whole brain were reduced in zinc deficiency (5). Apparently, the level of RNA is maintained in spite of reduced RNA polymerase activity. Previous studies of RNAse activity have shown slightly decreased RNAse levels in the zinc-deficient forebrain in comparison with both zinc-adequate controls (5). Thus it appears that the rate of RNA catabolism may be somewhat diminished in the zinc-deficient brain. This is in contrast to previous observations of increased RNAse levels in other tissues in response to zinc deficiency $(16,24,25)$. These other observations were made in adult animals and thus may reflect either an altered response depending on the tissue source or the levels of maturation of the animal.

Several previous observations have suggested that zinc deficiency interferes with normal protein synthesis or catabolism $(14,24,25)$. Analysis of the three test groups indicated that the protein content of the brains (expressed in milligrams per gram wet weight) were not significantly altered by the dietary regimes, but that the amount of protein per cell, i.e., per amount of DNA, did show a reduction in the zinc-deficient tissue at 6 and 15 days of age (Tables 3 and 4 ). This was in contrast to the protein per milligram DNA in the brains of the pups from the pair-fed dams; these pups had more protein per milligram DNA than the pups from the ad libitum-fed control dams. Thus zinc deficiency not only impaired formation of DNA and thus cell division, but it also decreased the amount of protein present in the cells. It seems possible that the decreased amount of protein was caused by impaired synthesis. Consistent with this interpretation were the polysomal profile patterns. Whole brain, postmitochondrial supernatants on a linear sucrose gradient revealed an abnormal distribution of material between monosomes and polysomes (Fig. 4). This finding was apparent at 5 days postnatally and continued through day 13. Inanition also reduced the amount of material in the polysomes relative to the amount in the monosomes, but the effect was not of the magnitude which occurred in the brains of zinc-deficient pups.

Speculative application of these findings to man, however tenuous, is appropriate, as zinc is essential for man. Plasma zinc concentrations have been shown to be low in infants with protein energy malnutrition (21). It has been suggested that such infants are therefore deficient in zinc. Such a speculation is reasonable in view of the basic diet of such infants. As zinc is essential for efficient utilization of dietary protein (29), it seems probable that zinc deficiency in infants with protein energy malnutrition compounds the protein deficiency, and may in part be responsible for the impairments in brain development and behavior which have been described in such infants. That zinc deficiency during the postnatal period of brain development may adversely affect behavior in the rat has recently been clearly demonstrated (11).

\section{SUMMARY}

Rats not supplied with adequate dietary zinc show growth depression of greater magnitude than that caused by inanition alone. The forebrains of such pups are significantly smaller than those from either pair-fed or ad libitum-fed, zinc-adequate controls. The cellularity of the brain is reduced by zinc deficiency. RNA concentrations appears to be minimally affected by zinc deficiency, but protein concentration per cell is reduced. Polysomal profiles displayed an altered distribution of material between polysomes and monosomes in brains of pups from pair-fed and zinc-deficient dams with the zinc-deficient brain having the greater magnitude of alteration. Adequate dietary zinc is necessary for normal growth and development of the brain of the suckling rat.

\section{REFERENCES AND NOTES}

1. Burton, K.: A study of the conditions and mechanism of the diphenylamine reaction for the colorimetric estimation of deoxyribonucleic acid. Biochem. J., 62: 315 (1956).

2. Dobbing, J.: Effects of experimental undernutrition on develop- 
ment of the nervous system. In: N. S. Scrimshaw and J. E. Gordon: Malnutrition, Learning and Behavior (Massachusetts Institute of Technology, Cambridge, Mass., 1968).

3. Fleck, A., and Munro, H,: The precision of ultraviolet absorption measurements in the Schmidt-Thannhauser procedure for nucleic acid estimation. Biochim. Biophys. Acta, 55: 571 (1962).

4. Food Nutrition Board, NAS/NRC.: Recommended Dietary Allowances, 1974.

5. Fosmire, G. J., A1-Ubaidi, Y. Y., Halas, E., and Sandstead, H. H.: The effect of zinc deprivation on the brain. Proceedings of the ACS Symposium on Protein-Metal Interactions. Advan. Exp. Med, Biol., 48: 329 (1974).

6. Grey, P. C., and Dreosti, I. E.: Deoxyribonucleic acid and protein metabolism in zinc-deficient rats. J. Comp. Pathol., 82: 223 (1972).

7. Guthrie, H. A., and Brown, M. L.: Effects of severe undernutrition in early life on growth, brain size and composition in adult rats. J. Nutr., 94: 419 (1968).

8. Hartree, E. F.: Determination of protein: A modification of the Lowry method that gives a linear photometric response. Anal. Biochem., 48: 422 (1972).

9. Hurley, L. S., and Shrader, R. E.: Congenital malformations of the nervous system in zinc-deficient rats. In: C. C. Pfeiffer: Neurobiology of the Trace Metals Zinc and Copper (Academic Press, New York, 1972).

10. Hurley, L. S., and Swenerton, H.: Congenital malformations resulting from zinc deficiency in rats. Proc. Soc. Exp. Biol. Med., 123: 692 (1966).

11. Lokken, P. M., Halas, E. S., and Sandstead, H. H.: Influence of zinc deficiency on behavior. Proc. Soc. Exp. Biol. Med., 144: 680 (1973).

12. Lowry, O. H., Rosebrough, N. J., Farr, A. L., and Randall, R. J.: Protein measurement with the Folin phenol reagent. J. Biol. Chem., 193: 265 (1951).

13. Luecke, R. W., Olman, M. E., and Baltzer, B. V.: Zinc deficiency in the rat: Effect on serum and intestinal alkaline phosphatase activities. J. Nutr., 94: 344 (1968).

14. Macapinlac, M. P., Pearson, W. N., Barney, G. H., and Darby, W. J.: Protein and nucleic acid metabolism in the testes of zinc-deficient rats. J. Nutr., 95: 569 (1968).

15. Patel, A. J., Balazs, R., and Johnson, A. L.: Effect of undernutrition on cell formation in the rat brain. J. Neurochem. 20: 1151 (1973).

16. Prasad, A. S., and Oberleas, D.: Ribonuclease and deoxyribonuclease activities in zinc-deficient tissues. J. Lab. Clin. Med., 82: 461 (1973).

17. Raulin, J.: Etudes cliniques sur la vegetation. Ann. Sci. Nat. Bot. Biol. Veg., 11: 93 (1869).

18. Rubin, H.: Inhibition of DNA synthesis in animal cells by ethylene diamine tetraacetate and its reversal by zinc. Proc. Nat. Acad.
Sci. U.S.A., 69: 712 (1972).

19. Sandstead, H. H., Gillespie, D. D., and Brady, R. N.: Zinc deficiency: Effect on brain of the suckling rat. Pediat. Res., 6: 119 (1972).

20. Sandstead, H. H., and Rinaldi, R. A.: Impairment of deoxyribonucleic acid synthesis by dietary zinc deficiency in the rat. J. Cell Physiol., 73: 81 (1969).

21. Sandstead, H. H., S., Prasad, A. S., Gabr, M. K., El Hifney, A., Mokhtar, N., and Darby, W. J.: Kwashiorkor in Egypt. Amer. J. Clin. Nutr., 17: 15 (1965).

22. Scrutton, M, C., Wu, C. W., Goldthwait, D, A.: The presence and possible role of zinc in RNA polymerase obtained from Escherichia coli. Proc. Nat. Acad. Sci. U.S.A., 68: 2497 (1971).

23. Slater, J. P., Mildvan, A. S., and Loeb, A.: Zinc in DNA polymerase. Biochem. Biophys, Res. Commun., 44: 37 (1971).

24. Somers, M., and Underwood, E. J.: Ribonuclease activity and nucleic acid and protein metabolism in the testes of zinc-deficient rats. Aust. J. Biol. Sci., 22: 1277 (1969).

25. Somers, M., and Underwood, E. J.: Studies of zinc nutrition in sheep. II. The influence of zinc deficiency in ram lambs upon the digestibility of the dry matter and the utilization of the nitrogen and sulphur of the diet. Aust. J. Agr. Res., 20:899 (1969).

26. Swenerton, H., and Hurley, L. S.: Severe zinc deficiency in male and female rats. J. Nutr., 95: 8 (1968).

27. Terhune, M. W., and Sandstead, H. H.: Decreased RNA polymerase activity in mammalian zinc deficiency. Science, 177:68 (1972).

28. Todd, W. R., Elvehjem, C. A, and Hart, E. B.: Zinc in the nutrition of the rat. Amer. J. Physiol., 107: 146 (1934).

29. Underwood,. E. J.: Trace Elements in Human and Animal Nutrition, p. 222 (Academic Press, New York, 1971).

30. Winick, M., and Noble, A.: Cellular response in rats during malnutrition at various ages. J. Nutr., 89: 300 (1966).

31. Mention of a trademark or proprietary product does not constitute a guarantee or warranty of the product by the United States Department of Agriculture, and does not imply its approval to the exclusion of other products that may also be suitable.

32. Dr. G. J. Fosmire is a Research Chemist, United States Department of Agriculture, Agriculture Research Service, North Central Region, Human Nutrition Laboratory.

33. Dr. Y. Y. Al-Ubaidi is affiliated with the Parke De Watt Laboratory, Chicago, III.

34. Dr. H. H. Sandstead is Director, United States Department of Agriculture, Agricultural Research Service, North Central Region, Human Nutrition Laboratory.

35. Requests for reprints should be addressed to: H. H. Sandstead, M.D., United States Department of Agriculture, Agriculture Research Service, North Central Region, Human Nutrition Laboratory, 2420 2nd Ave. North Grand Forks, N.D. 58201 (USA).

36. Accepted for publication September 6, 1974. 